Mem. Inst. Oswaldo Cruz, Rio de Janeiro, Vol. 80(3) :363-366, jul./set. 1985

\title{
THE CHANGING PATTERN OF PATHOLOGY DUE TO SCHISTOSOMA MANSONI INFECTION
}

\author{
ZILTON A. ANDRADE \& JOSE CARLOS BINA
}

A survey of the autopsy data on hepatosplenic schistosomiasis during periods, before and after the advent of new chemoterapeutic drugs, revealed that: a) the pathological presentation was the same for the two periods; $b$ / the number of cases in the last five years is progressively decreasing; c) hepatosplenic disease due to schistosomiasis is becoming rare in young people. These data represent a change in the pattern of pathology in schistosomiasis, probably related to new chemotherapy.

First of all, the very title of this presentation may be questioned. There are no convincing data from human material proving that the pattern of pathology due to $S$. mansoni infection is really changing. Analysing recent necropsy cases, the pathologist in Northeastern Brazil still observes classical pipe-stem fibrosis of the liver, with esophageal varices and splenomegaly, eventually associated with schistosomal pulmonary arteritis with chronic cor pulmonale, glomerulonephritis, splenic lymphomas etc. On the other hand, a close look at accumulated material from the last 25 years, will disclose that some changes, not qualitative but rather quantitative, seem to be taking place. When these latter observations are placed against a background of recent clinical, epidemiological and experimental findings, the significance of these quantitative changes may become more apparent.

Until some $10-15$ years ago, schistosomiasis in the large endemic area in Northeastern Brazil was on the increase, with transmission occurring even in peri-urban locations. Control measures were sporadic, limited and of course inefficient. The single event that caused the greatest impact on this parasitic disease was the introduction of new and highly effective curative drugs.

The advent of effective and safe drugs which can be administered by mouth in a single dose and that can cure from 60 to 95 per cent of cases of schistosomiasis and reduce egg excretion and worn load in almost 100 per cent of the cases, has made programs of large scale treatment of populations possible. As a consequence of such programs we know that chemotherapy alone is not sufficient to control schistosomiasis, since the cured individuals soon appear to be re-infected. However, confirming earlier findings, reinfected individuals tend to acquire light infections, that do not progress to serious disease. Therefore, curative treatment of schistosomiasis was seen to prevent the development of hepatosplenic schistosomiasis (Bina, 1977). Curative chemotherapy may even cause hepatosplenic disease to regress completely or partially (Bina \& Prata, 1983). These events involving a considerable number of the infected population may affect the type of pathological material in schistosomiasis that a pathologist working in an endemic area is used to seeing.

\section{How modem chemotherapy of schistosomiasis may be affecting the presentation of its pathology}

This section concerns only hepatosplenic schistosomiasis, since the lesions in mild infections may be either completely reversed or remain as focal negligible pigmented scars after specific treatment. As stated before, pathology of hepatosplenic schistosomiasis continues to appear the same as usual, but one may note that the overall number of necropsy cases is progressively decreasing in recent years, that the cases occurring in younger patients are becoming rarer and that there seems to be more cases in which schistosomiasis appears as a secondary process associated with other major and unrelated diseases. These latter cases may indicate that patients with extensive portal fibrosis, which become arrested and compensated after treatment, are now living longer and dying of other diseases. These are preliminary considerations based on the analysis of pathological material from the University of Bahia Hospital (Hospital Prof. Edgard Santos), in the last 25 years. Recently, 232 necropsies performed in hepatosplenic cases during the period 1956 to 1975 were reviewed (Andrade \& Bina, 1983). For this present report and a comparative study, a review of

Paper presented to the Expert Committee on the Control of Schistosomiasis (WHO) Geneve, 8-13 November, 1984.

Centro de Pesquisas Gonçalo Moniz - FIOCRUZ, Rua Valdemar Falcão 121, Brotas, 40000 Salvador, BA, Brazil. Received for publication March 27th and accepted May 24th, 1985. 
33 necropsies performed during the period 1976-1980 was made. All cases of hepatosplenic schistosomiasis were included. Diagnosis was made in the presence of typical pipe-stem fibrosis and evidences of portal hypertension. Figure 1 shows that the number of cases necropsied in the Hospital, which tended to remain stable at around 6.7 per cent until 1975 (over a 20 year period) progressively decreased afterwards. This trend could also be attributed to other factors, such as installation of hospital facilities in rural areas, changes in admission policy of the Hospital, etc. However, analysis of figure 2 which shows the percentage of cases in the two periods, related to age and incidence, reveals that in the last five years, individuals dying with hepatosplenic schistosomiasis tended to be older than in the previous 20 years. In 11 of the 33 cases seen in the period 1976-1980, the hospitalization and death of the patients were due to other major unrelated diseases. Regarding the other aspects, the pathology of hepatosplenic schistosomiasis in the two groups of cases was quite similar.

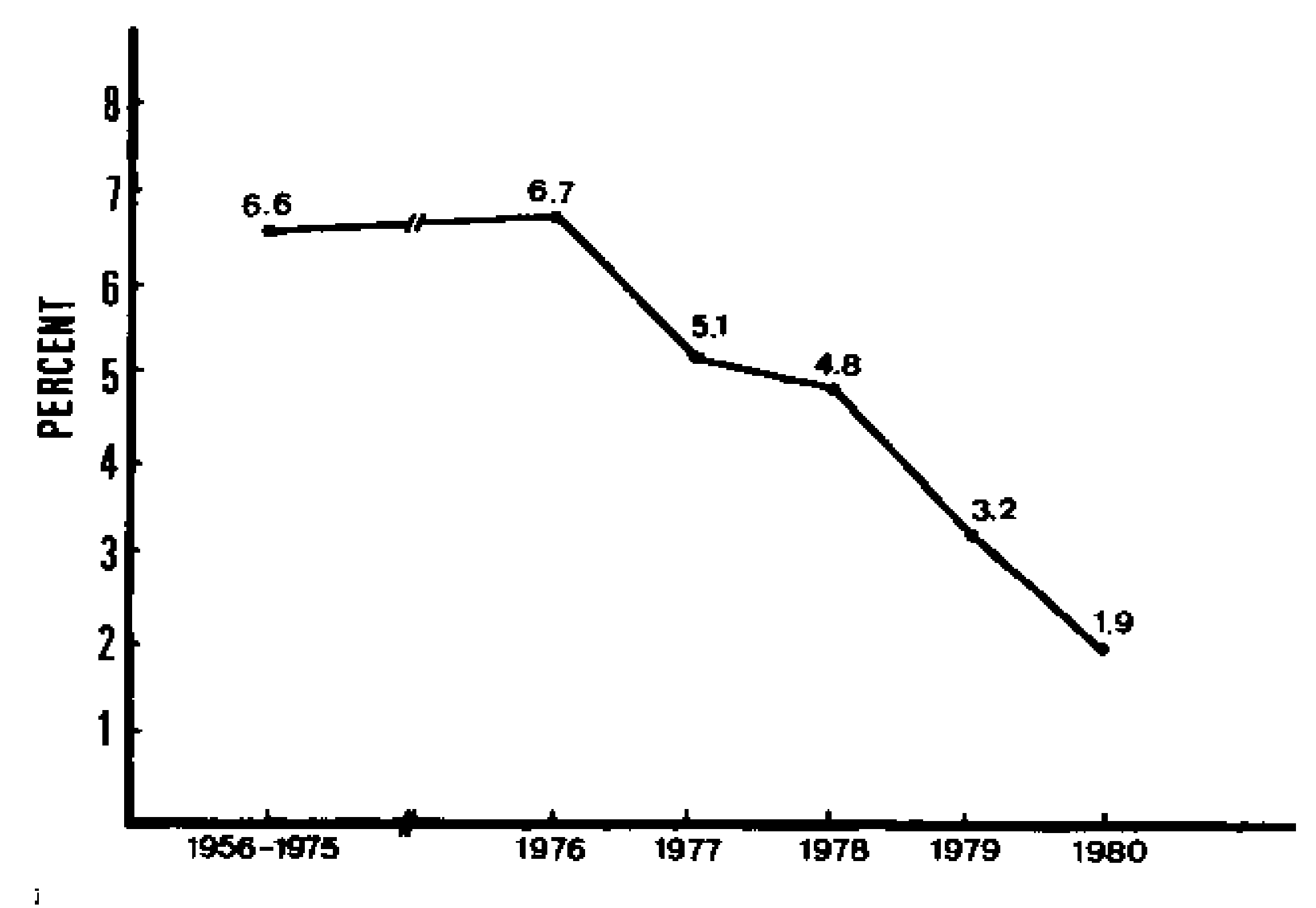

Fig. 1: percentage of necropsied cases of hepatosplenic schistosomiasis during the periods 1957-1975 and 1976-1980. Hospital Prof. Edgard Santos. Bahia-Brazil.

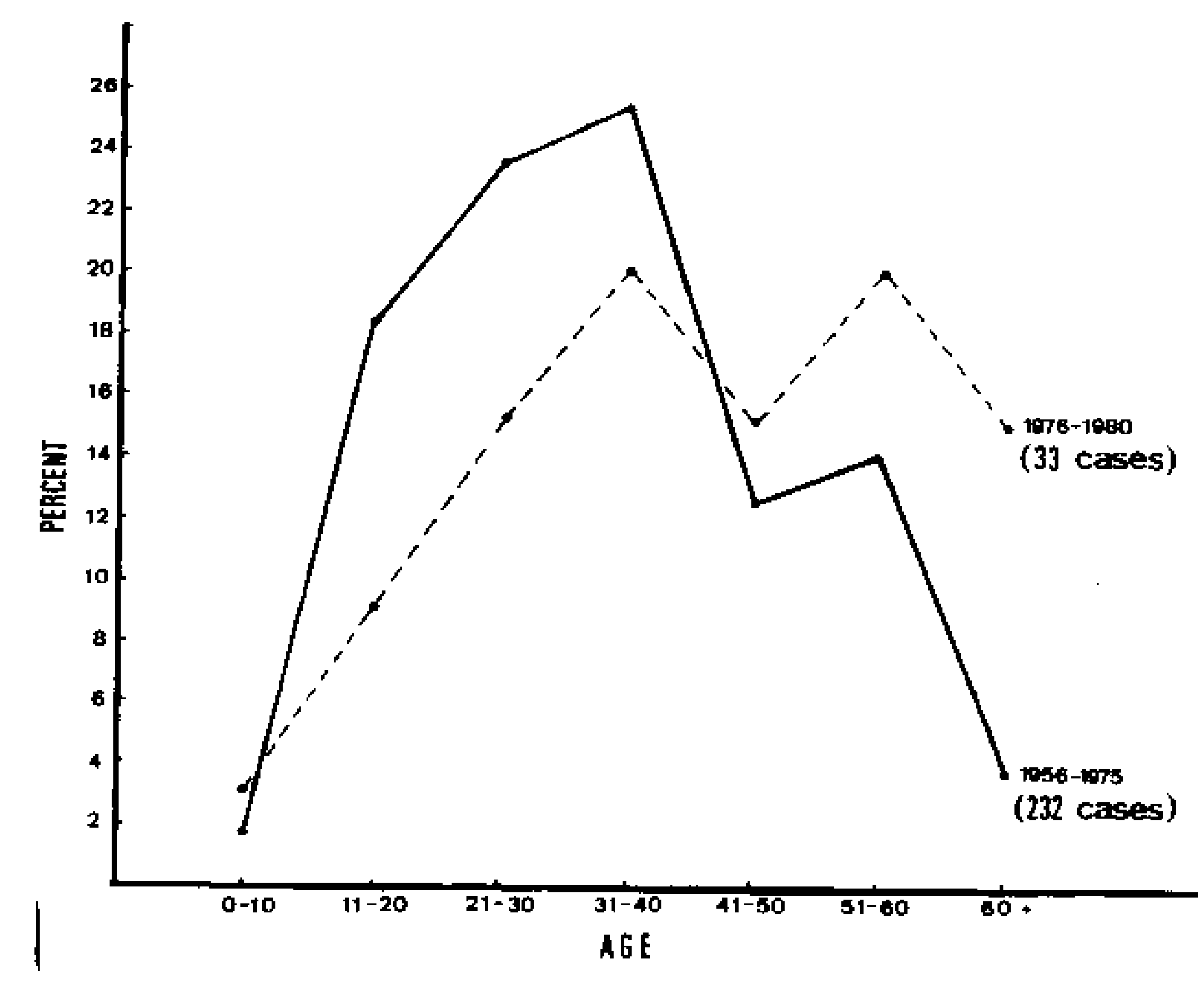

Fig. 2: distribution of necropsied cases of hepatosplenic schistosomiasis (in percentage) according to age and during the periods 1956-1975 and 1976-1980. Hospital Prof. Edgard Santos. BahiaBrazil. 
It is very difficult, if not impossible, to draw the conclusion that the pattern of pathology due to $S$. mansoni infection is changing, based only on the observations of the human cases at necropsy. Probably, the coming years will help to turn the picture clearer.

\section{Experimental aspects}

Experimental studies have suggested that the pathology of schistosomiasis in humans is capable of being modified through the impact of modern chemotherapy. Mature schistosome eggs are the main pathogenetic factor producing lesions in schistosomiasis, which are mainly present in the liver. Effective chemotherapy first interferes with egg production and soon makes the periovular granuloma to shrink and be totally or partially reabsorbed. Even the complex, destructive and obstructive intra-hepatic portal vein lesions caused by schistosomiasis in the mouse, can be almost completely repaired within one or two months after treatment. The periovular granuloma becomes smaller and smaller through a process of collagen densification, fibrolysis and fibroclasia, while neoformed blood vessels bypass the fibrous scar and re-establish blood flow, remodelling them toward a near normal vasculature (Andrade \& Brito, 1981). In the mouse model, the schistosomal pulmonary arterial lesions do not have the same possibility as the portal vein lesions to be repaired after treatment. Drug treatment can cause a dramatic improvement on the periovular granulomas present in the alveolar lung tissue. However, the arterial changes undergo defective repair and the obstructive nature of the lesions remains unchanged (Almeida \& Andrade, 1983). Therefore, judging from experimental data, it seems that the schistosomal pulmonary lesions causing chronic cor pulmonale in man are unlikely to be affected by chemotherapy.

The clinical observation that patients with schistosomiasis seem to maintain a residual immunity following curative chemotherapy, has also been investigated experimentally. When treated and cured animals are re-infected, fewer adults worms are recovered from the portomesenteric system, as compared to normal controls. The existence of porto-systemic collateral veins provoked by portal hypertension in the previously infected animals, may divert the reinfecting maturing worms towards the peripheral vascular system, where lack of a proper ecologic environment may cause their death. The reduction in worm load during the challenging infection, would therefore not result from immunological factors, but from a "leaking" portal system (Wilson, Coulson \& Mc Hugh, 1983).

However it should be pointed out that the cured and re-infected animals are able to modulate the first granulomas of the challenging infection and will show strong cutaneous and pulmonary reactivity to the migrating schistosomula. Six months after treatment in the mouse, the immunity is no longer detected and the cutaneous and pulmonary reactivity as well as the ability to form small, discrete periovular granulomas disappear (Andrade \& Brito, 1982). If a residual immunity persists in animals with complete parasitological cure, the situation may be still better for man, where treatment may not erradicate all the worms, thus helping the persistance of concomitant immunity. A striking rise in eosinophil and antibody levels after a second treatment in people "cured" of schistosomiasis has been observed (Silva et al., 1976), and this has been interpreted as due to the death of worms remaining from the previous treatment.

Perhaps the changing pattem of pathology due to $S$. mansoni infection is only being initiated and that more and more study are necessary to establish its extent and significance.

\section{RESUMO}

Uma revisão dos dados de necrópsias realizadas em portadores da forma hépato-esplênica da esquistossomose, feita em dois períodos, antes e após a introdução das novas e efetivas drogas contra o $S$. mansoni, revelou que: a) as lesões encontradas foram qualitativamente as mesmas nos dois períodos; b) a percentagem dos casos hépato-esplênicos mostra decréscimo progressivo nos últimos cinco anos do estudo; c) os casos de esquistossomose hépato-esplênica estão se tornando raros em jovens. Tais elementos constituem uma mudança no padrão de apresentação da doença, possivelmente relacionada com a introdução da nova quimioterapia curativa.

\section{REFERENCES}

ALMFIDA, M.A.C. \& ANDRADE, Z.A., 1983. teffect of chemotherapy on experimental pulmonary schistosomiasis. Am. J. Trop. Med. \& Hyg., 32 :1049-1054.

ANDRADF, Z.A. \& BINA, J.C., 1983. A patologia da forma hépato-esplênica da esquistossomose mansoni em sua forma avançada (Estudo de 232 necrópsias completas). Mem. Inst. Oswaldo Cruz, $78: 285-305$.

ANDRADE, Z.A. \& BRITO, P.A.. 1981. Evolution of schistosomal hepatic vascular lesions after specific chemotherapy. Am. J. Trop. Med. \& Hyg., $30: 1223-1227$. 
ANDRADE, Z.A. \& BRITO, P.A., 1982. Curative chemotherapy and resistance in murine schistosomiasis. $A m$. $J$. Trop. Med. \& Hyg., $31: 116-121$.

BINA, J.C., 1977. Influência da terapêutica específica na evolução da esquistossomose mansoni - Thesis. University of Bahia, Faculty of Medicine, Bahia, Brazil.

BINA, J.C. \& PRATA, A., 1983. Regressão da hepatoesplenomegalia pelo tratamento específico da esquistossomose. Rev. Soc. Bras. Med. Trop., $6: 213-218$.

SILVA, L.C.; HOSHINO-SHIMIZU, S.; KANAMURA, H.; STRASSMAN, P.C.; CAMARGO, M.E.; SETTE, H. JR.; LOPES, D.; CHAMONE, D.A.; RAIA, S. \& SILVA, G.R., 1976. Serum antibody changes after repeated chemotherapeutic series in "parasitologically cured" patients with schistosomiasis mansoni. Rev. Inst. Med. Trop., Säo Paulo, $18: 206-210$.

WILSON, R.A.; COULSON, P.S. \& Mc HUGH, S.M., 1983. A significant part of the "concomitante immunity" of mice to Schistosoma mansoni is the consequence of a leaky hepatic portal system, not immune killing. Parasite Immunology, 5 :595-598. 